\title{
Conspectus
}

\section{Emotions as Reasons in Public Arguments}

\section{John S. Nelson}

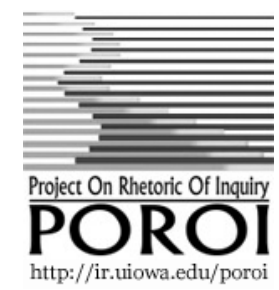

Poroi, 4, 1, March, 2005

1 If ethos is the word for our previous issue of Poroi (3, 2, December, 2004), pathos is the word for this one. Pathos appeals to passions; it stirs sentiments; it mobilizes emotions. All the essays in this sixth issue analyze public forms and personal capacities of pathos. Together they argue powerfully for greater attention to political aesthetics, particularly in coming to terms with public arguments. These reach from cultures to technologies and from campaigns to sciences.

2 The Poroi Symposium on Urban Rhetorics of Race is a project of J ames Throgmorton, who specializes in urban and regional planning. Situating himself in a nexus of comparisons between Louisville in America and Berlin in Germany, Throgmorton complements his planning perspectives with literary reflections from Christine Gerhardt and communication considerations from Leslie Hahner. All three emphasize politics of race and ethnicity, and all three show these constructed through rhetorics more ample in pathos and ethos than logos. Gerhardt addresses how Americans have experienced Berlin as a site of racial conflict before and after the Wall came tumbling down. Hahner explores how Louisville is trying to use its new Muhammad Ali Center to hide its own history of racial division, one that the Center would do better to face. Throgmorton ties the Gerhardt and Hahner accounts into a tale of two museums that reveals how racialization continues in current cultures.

3 Modern epistemologies portray pathos as appealing to our sympathy, while late-modern aesthetics display pathos as engaging our empathy. But from philosophy and communication, David Depew explains how the postmodern turn away from empathy shows it to be a residual "repair concept." It was to do the work that "sympathy" no longer can; yet even "empathy" has since come to be rejected in aesthetics. This Depew thesis initiates a Poroi Symposium on Word Tours of Empathy. From literary and cinematic criticism, Russell Scott Valentino follows some of the 
same fault lines. His rattle erratically back from literary realism in the nineteenth century to Shakespeare, even while implicating Bahktin and Nabokov in the twentieth. Along the way, Valentino shows, we may find useful principles for reading, criticizing, and translating literature.

4 Television is the topic for rhetorician Bruce Gronbeck. He defends sentimental images as major resources for political communication in America. Tapping Adam Smith on sympathy, Gronbeck ranges across televised speeches, convention videos, and campaign spots to show how passionate pictures can construct good politics. He turns the tables on critics of television by tracing how visualized emotions connect people patriotically, celebrate identities communally, and help us take politics personally. Gronbeck's contention is that current politics need pathos for reasons practical, theoretical, but especially ethical.

5 The ensuing argument, my contribution to this conversation, reminds us that pathos is reasoning. The modern injunction is not to be carried away by feelings. The idea is to step back from undue engagement in any setting, from heated passions of the moment, and the postmodern multiversity continues to embrace this academic ideal. Yet public arguments present a different picture of pathos. They show us how moral and other practical judgments are passionate. To direct - let alone induce - action, they fill us as much with feeling as information. Or better, they fill us with feeling as information, and information as feeling. Moreover they encourage us to assess our situations through diverse complexes of emotion rather than one mode only of cool calculation for efficient means to given interests. As examples of public arguments, political advertisements on television help indicate how there are multiple rationalities for politics. They also show how each political rationality is, in important part, a distinct form of pathos. Then we can learn how to call on modern, instrumental rationality alone is to lose many of our arguments, much of our minds, and most of ourselves.

\section{Public Arguments}

An excess of reason is itself a form of madness.

Kim Stanley Robinson (2004, p. 244)

6 In the church of reason, logos is king (Pirsig 1974). Here the metaphors aren't so much mixed as matched. The academy, the university, the multiversity: all seek to exclude modes of argument 
other than the strictly rational, and all define rationality as intellection or cognition by contrast with passion. Reason is not emotion, imagination, volition, reputation, even narration. Neither pathos, ethos, mythos, nor tropos need apply (Nelson 1998, pp. 99-149). Science is the height of civilization; and science is fact and logic, not value or invention.

7 The trouble with this fantasy is that facts are made, logics are many, and scientists are humans: individually embodied and working best in communities of inquiry complete with politics aplenty. In fact, rhetorics rule: cognition is hot; reasoning is motivated, even in science; and our diverse rationalities are networks of feeling, figure, and story as well as information or logic (Nelson 1983; Lodge 1995). The need is now to make room in accounts of argumentation and reasoning for the many elements that modern rationalities - cool, abstracted, disembodied, streamlined, strategic - sometimes omit (Frank 1988).

8 Public arguments are important places to recognize all this, so that standards for proof and notions of reason keep pace with technologies of communication and devices of persuasion. Scientific arguments are public in a limited sense: open to any who can address them. Political arguments are public in a larger sense: addressed to any who open to them. And both kinds of public arguments are becoming multimediated. In classes, conventions, laboratories, and online journals, science is becoming multimedia scholarship. The PowerPoint slides, aural data, visual models, and virtual-reality devices are intrinsic to doing science in the twenty-first century. The screens, sounds, and simulations of film, television, and computers are crucial for the century's deliberations, elections, movements, and regulations. Ours are becoming multimedia politics. These can be fuller in body and better at feeling than more constricted media or politics.

9 How should we treat public arguments in multimediated times? Not in the ways we have been trying to assess political spots on television. Political telespots are a fast-evolving frontier of public arguments in the larger sense. To evaluate them, the academy and the media are invoking pseudo-scientific criteria of "logical" argument or anti-political norms of "rational" persuasion. These impose impossible canons of "truth," unfortunate strictures against "distortion," foolish requirements for "information," and misbegotten ideas of "judgment." Especially they strive to exclude emotions from public arguments. We would do better to welcome the inevitability of emotion along with its indispensability for 
information, judgment, and reason as well as action.

10 To help appreciate this, we can examine the uses of emotions as reasons in polispots. These uses show how being rational in public arguments is being adequately emotional. The passions of others can be good, valid reasons for their public claims. Therefore polispots take care to display the emotions of candidates, critics, endorsers, and more. Our own feelings also can become reasons for public arguments, so effective ads often provoke appropriate emotions in viewers. Media commentators and scholars mistakenly treat both sites and sets of emotion as manipulations that short-circuit rationality rather than complete it. Yet how emotions can work as reasons in public arguments becomes especially in clear in such multimedia argumentation. Modern rationalities favor words, logos, largely uninflected text. Telespots add genres, images, voices, musics, and other sounds. As public arguments, political ads on television can be good at communicating emotions as reasons.

\section{Modern Rationality}

Dispassionate; sensible; calm; reasonable.

A thinking machine.

Kim Stanley Robinson (2004, p. 248)

11 The modern, western dichotomy between reason and emotion can be more misleading than helpful, especially in parsing political communication. Campaign spots on television are no exception. They demonstrate how prominent emotional appeals are in political persuasion. They indicate how implausible it can be to separate information from emotion. They show how emotions can be intrinsic to political reasoning. And they suggest how distinct kinds of politics can be political rationalities that amount in some respects to different complexes of emotions.

12 To this point, studies of emotions within political communication in general or televised advertising in particular tend to take one or more of four approaches. They ignore emotions as irrelevant for cognition or secondary for reasoning (Graber 1988; Biocca 1991). They condemn emotions as markers of propaganda (J owett 1986; Combs 1993). They distrust emotions as signs of manipulation that disrupt reasoning or depress participation (J amieson 1992; Ansolabehere 1995). Or they defend emotions as forces of motivation that engage citizens, activate vigilance, and facilitate persuasion (Huddy 2000; Brader 2005). Across all these 
approaches, though, the shared assumption is that emotions as modes of passion (at least should) remain categorically discrete from data or information as claims of fact and reasons or warrants as claims of logic.

13 The premise is common among modern epistemologists, survey researchers, cognitive experimentalists, neurobiologists, even political rhetoricians. Modern philosophers dualize mind and body, then place reason in mind and emotion in body (Damasio 1994). Surveyers identify feelings with values in contrast to facts, logics, or ideas (Nelson 1977). Cognitionists treat emotions as tags somehow separable from factual or logical contents of experience and intellection (Fiske 1991). Neurologists localize fields of brain function to contrast ratiocination of various sorts with emotions of several kinds (Damasio 1999, 2003). From Aristotle (1991) onward, rhetoricians segment persuasion into logos as logics or topics, ethos as authority or credibility, plus pathos as passion or emotion.

14 The vague but pervasive implication is that emotions are illogical and unscientific. By most definitions, they are non-rational; by many irrational; by some anti-rational. Inquiry and judgment should avoid them: better to think like a machine than feel like a human, if accuracy and validity are at stake. If cognition proceeds largely and appropriately apart from emotions, moreover, so should communication - at least when we must get something right, whether in the academy or the polity. To cull the wheat from the chaff of political ads means stripping the emotions aside to test for the kernels of truth in claims about plans, policies, or performances. Thus the ad watches inspired by scholarship on political communication police distortions far more than they sort through passions, even though they presumably would treat emotions as distortions if they were to give feelings frontal attention (J amieson 1992, 2000; West 1992, 2001).

\section{Ad Watches}

I believed instead that the rational spirit should not indulge such passion, but feed only on the Truth ... Umberto Eco (1983, p. 15)

15 Toward the end of the twentieth century, some scholars joined hands with journalists from print and television to police those public arguments we know as campaign telespots. The premise has been that political ads, especially on television, will play fast 
and loose with the truth unless checked by an outside power. The implication is that the images, voices, and musics of political spots lend themselves to distortions of reason and manipulations of emotion that traduce public judgment of candidates and causes. Viewers cannot defend themselves against such propaganda, except by a pervasive cynicism that corrodes representative politics. Competitors can counter smears by opponents only when campaign money distributes itself more evenly than usual, and even then the result is less an effective correction of claims or assignment of responsibilities than a diffuse public cynicism about all politicians. Notwithstanding complaints that the press already plays too great a role in selecting candidates, the insistence has become that the press referee electoral contests, particularly the contents of political spots on television (Patterson 1980, 1993).

16 There are many ways to tell the story of standards for political ads as public arguments. Some accounts start even before the American advent of televised campaign spots in 1950, but a more recent story should suffice here. It tells how George H. W. Bush won the 1988 presidential election in the summer of that year when Roger Ailes unleashed a barrage of attacks ads against Michael Dukakis. These spots undid a seventeen-point lead in opinion polls by defining a little-known Dukakis as pro-crime, protax, anti-military, and anti-environment. For weeks, neither a stunned Dukakis nor a neutral press did much in response (Galston 1989). By the time Dukakis and the press objected to the Bush attacks as outrageous misrepresentations, their protestations were too little and too late. Clever lies, potent images, and sinister sounds had mobilized voters to doubt Dukakis just where journalists and scholars knew Dukakis to be strong and Bush weak (J amieson 1992, pp. 3-9).

17 'Twould be a shame, the call came, for the press to let this happen again. Scions of the establishment press such as David Broder (1990) and Paul Taylor (1990a, 1990b) roused their colleagues to generate ad watches in print and truth squads on television. As Dean of Penn's Annenberg School of Communication, Kathleen Hall J amieson (1992, pp. 15-159) has coached telejournalists on video techniques to police truth in political advertising yet avoid inadvertent "news ads" that can yield big and uncritical audiences for the worst in mud and distortion. Now as Director of Penn's Annenberg Public Policy Center, she has sponsored a Web site that checks truth claims for political spots and speeches. Any number of journalists and scholars have added to the hue and cry against "negative ads;" and many have contributed to print or TV reviews 
of spots for their factual inaccuracy, invitations to misinference, and sensational attacks (Alter 1990; Kurtz 1996). Elections from 1990 onward have included myriad "mud squads," "reality checks," "ad zappers," and the like in newspapers, news magazines, morning shows, news broadcasts, and pundit programs. Let it not be said that determined scholars and journalists never concert themselves to make any real difference in public affairs. The ad police have made themselves a staple in American elections.

18 Even some of the initial advocates of ad watches have developed hesitations about their effects (J amieson 2001, pp. 121-122). The intention was to make spots more truthful and citizens more informed. Along the way, there probably has been the hope that ad watches would help contributors and voters punish the worst offenders by redirecting donations and votes to other candidates. Yet sometimes the ad watches seem counterproductive. Although taking visual and verbal care to "distance" viewers from the pieces of spots they show, ad watches still can create powerful "news ads" from particularly colorful offenders (J amieson 1992, pp. 121-159). Sometimes the news makes these reverberate for days or weeks throughout the media as echo chambers. What happened in 2004 with the notorious Swift Boat spots is a clear case in point. Often ad watches lack the conceptual or informational resources to come to decent terms with the spots they review (Nelson 1997, pp. 2932; Ansolabehere 1996). The ad watches aggravate the overall climate of cynicism about politics promoted of late in American news (Richardson 2003, pp. 89-109). And by ignoring most dynamics of political communication, the ad watches seldom help people understand how spots actually work (Nelson 1997, pp. 5869). Among the dynamics given short shrift by ad watches are the emotions spurred and tapped by telespots.

\section{Political Reasoning}

Reason only functions when the emotions are involved. J ohn le Carré (1996, p. 91)

19 Even the chief architect of modern rationality, David Hume, insisted that emotion and imagination are indispensable to reason. This is the Hume of cool, dispassionate judgment, the one who gave us the modern dichotomy between is and ought, fact and value (1739-40). This is Hume the cognitivist, who invented the idea of rational judgment as "proper discernment" by an idealized, "disinterested spectator" practiced in critical reflection (1777). Nonetheless Hume explained that the merit of the matter emerges 
for critical discernment through vivid activity of the imagination. It brings objects of judgment fully before the mind's rational-I. It does this so that the rational judge experiences objects adequately, hence feels them accurately. The feelings are emotions. Upon proper discernment, how in detail might I approve or disapprove objects? What specific sentiments does each evoke in me? Reason and sentiment must concur, Hume wrote. That is because our reasons must include our emotions when we take care to experience objects amply, adequately, properly. Warranted judgments in public arguments depend for Hume on emotions as reasons. Disproportionate feelings can overwhelm us, and improperly provoked emotions can misinform us. Yet humans are not computers, even when it comes to reasoning (Nesbitt 1980; Billig 1989). Therefore increasing our capacity for emotion enhances our ability to reason.

20 Re-enter polispots. Scholars have been surprised to learn that citizens get more ample and effective campaign information from political ads than televised news (Graber 1988; J amieson 2000). Both outdistance print. Consistent with Hume, political cognitionists acknowledge that the multimedia combination of audio, video, and verbiage activates more senses as channels for more information (Graber 2001). Likewise all of us can recognize that audiovisual experiences augment imagination more extensively than print does when bringing objects adequately before the bar of judgment. But these are advantages of television, holding for spots and news. Why do polispots surpass newscasts as sources of relevant and remembered information for voters? Why don't the news ethos of impartiality and logos of complication generate more information and better reasoning?

21 Ads typically have higher production values than news. The superior sights, sounds, and words probably boost the impact of polispots. Yet the contrast is clearer for commercials, which get the lion's share per minute of production money and talent. A bigger advantage for polispots is in timing (West 2001). Newscasts detail candidates and issues early in campaigns, when voters are inattentive, then resist doubling back because old news is no longer news. Ads come throughout campaigns and cluster at their height, when and where attention is greatest. Around the clock and across the dial, polispots disperse and repeat themselves far more than newscasts. Frequency and repetition improve retention, recognition, and ratiocination. But the biggest edge of polispots over telenews is in pathos. News stays neutral in elections, whereas ads emote. Or more specifically, news dampens 
passions. It turns them toward the cool, calm, and collected complex of modern rationality in order to stay respectable as reporting events and analyzing facts. Political ads, by contrast, mobilize emotions that are many and varied to attain persuasion by promoting sentiments and instructing judgments. This is just as Hume and other philosophers of reason would want; it is just as we should appreciate.

22 Newscasts mainly tell but also show elections, typically from an emotional distance. Ads mostly dramatize campaigns, engaging and informing our passions. Therefore telespots deliver vicarious, virtual, and symbolical experiences of the candidates, supporters, opponents, topics, and more. These modes of experiential persuasion help us figure out how to feel about their performances and priorities: a crucial step in reasoning what to do (Nelson 1997, pp. 195-232). Emotions also move us to act on the resulting judgments, when polispot passions push us past thresholds of indifference. On the whole, though, the pathos of ads probably overcomes weak will far less than it helps us reason in the first place.

\section{Emotional Functions}

Emotions are an essential part of the ability to reason. Doris Graber (2001, p. 37)

23 Reasons are not the only roles for emotions in telepots. Particularly by music or tone of voice at the beginnings of ads, feelings like those aroused by fanfares activate viewer attention. Especially toward the ends, emotions also move viewers to action (Nelson 2004d). Admonished in 1972 that "The people are paying for this campaign with their hard-earned dollars," you viewers were to be moved by feelings of solidarity and guilt to "send what you can to McGovern for President." From Eisenhower onward, telespots play upbeat music or show happy parades to help people experience climbing onto the candidate's bandwagon. Finally, telespot passions do sometimes replace, prevent, or pervert reasoning. J amieson (1992) specifies this for the "visceral" feelings mobilized by Bush spots in 1988. These three roles for telespot emotions have been studied through analyses, experiments, focus groups, surveys, and more. But the further roles of emotions as reasons in telespots have gone largely unrecognized. 
24 First, major claims about candidates require emotions for evidence. Do candidates "care deeply" about education or employment? Are candidates "outraged" about crimes or taxes? By voices, gestures, and musics, telespots have candidates enact emotions to warrant such claims, as well as show their sincerity or certify their promises. Bad ads argue against themselves in these ways. Paul Tsongas trumpeted himself in 1992 as "the environmental candidate for president," but the funereal blackand-white of his telespot argued against optimism for his environmental program. Green-and-white, Paul Wellstone's iconic bus felt clean and bright to corroborate his anti-corruption, proenvironment credentials (Szasz 1994; Boynton 1995, 1996, 1997; Nelson 1997; DeLuca 1999).

25 Similar considerations hold for testimonials. Eleanor Roosevelt's wooden endorsement of J FK in 1960 impugns itself. Likewise the man-on-the-street recitations in 1968 for Hubert Humphrey counter-evidence by stilted vocal tones their claim that "these are critical times for America." By contrast, Ronald Reagan's 1976 telespot for Gerald Ford carries conviction as a vehement attack on J immy Carter.

26 Second, polispots must mobilize emotions for viewers even to comprehend many claims, a prerequisite for presenting or assessing evidence. Comprehension depends on what the Greeks named mimesis, the middle ages called imitatio, and the modern epistemologists reconstruct as representation (Auerbach 1953; Scarry 1994; Nelson 2004c). Reagan's 1984 spots contended it was "morning again in America." What did that mean? To understand the claim, viewers needed to feel new political days dawning. The spots are renowned for promoting emotions of pride and refreshment through lush, filtered colors and richly orchestrated music. "Imagine," two 1988 spots directed, the utopia from a Dukakis presidency that knows "the best America is yet to come." What could that mean? The spots specify their instruction by having viewers experience in participatory close-ups and heroic slow-motion a set of scenes similar to Reagan's four years before.

27 When telespot emotions fail to mime or represent for viewers the contents of claims, spots confuse viewers. The black humor of the 1988 "Packaging of the President" spots against Bush managed to escape viewers who contacted the Bush campaign to complain about baffling ads. The stentorian voiceover for the primary version of "A Town Called Hope" emoted pride, not hope, and the 
Clintonites used the candidate's warm voiceover to remake the spot for the general election. Dole ran a 1996 spot with no sound effects that wondered mildly, "Do you really know Steve Forbes?" When the same pictures and voiceover ran in a second spot with sound effects from horror, viewers could recognize the question as a devastating indictment.

28 Third, emotions make logical connections in some telespots. Vote against incumbents, an ad argues, because they're allowing huge deficits. What is the logical link, the suppressed premise? Big deficits are bad because they harm people. A notorious lesson from the 1980s onward is that such words do not make the connection for many people. Bolster the words with statistics about impacts on interest rates or economic activities, and the connection remains insecure. Add a debt sign with numbers racing upward, and people experience that deficits aggravate debt, but they do not yet sense the harm in this. A persistent challenge for political advertisers has been to mobilize the emotions that make the link between deficits and injuries.

29 Vocal devices of worry, anger, scorn, and such seldom work. Spots for Walter Mondale in 1984 had recourse to horror music from the Halloween movies to help people feel the monster debt lurking, growing, coming to get them. But the breakthrough acknowledged by advertisers did not happen until 2003 when a spot about "Child's Play" won wide MoveOn.org sponsorship by showing how iconic children in the near future would work at menial jobs in coming to terms with the cross-generational consequences of ballooning deficits by the federal government. The organization followed in 2004 with a couple of parallel spots that dress seniors in service garb to perform menial work way past the time for retirement because a broke government cannot pay for Medicare, Social Security, and such. Logical connections not felt are connections not made.

30 The western ties between logos and the eyes mean that visualization is the main telespot tool for making logical connections through emotions (J ay 1993; Huddy 2000). This is the kind of emotive imagination that Hume recognized as crucial for reasoning. Words often visualize. Environmentalists need to help people reason in micrograms and other quantities remote from everyday discourse, so they resort to rhetorical devices like PATEOTS, the period at the end of this sentence. As an activist says, "a microgram is about equal to one PATEOTS. A part per million is a drop in a railway tank car - that's what the chemical 
companies always say, to make it sound less dangerous. If all the baby seals killed last year are laid end to end, they would span a hundred football fields. The tears shed by the mommy seals would fill a tank car. The volume of raw sewage going into the Harbor could fill a football stadium every week" (Stephenson 1988, p. 22). At times, video visualizes even more vividly. Add sounds, and telespots approach full-bodied, virtual realities that can make information and emotion more accurate and adequate for judgment (Nelson 2000).

31 Fourth, emotions help define and defend key terms in political arguments. Is the nuclear bomb for fighting ordinary wars? Hear the indignant narrator in 1964 deliver Barry Goldwater's answer that it is "just another weapon." Does the scorn feel appropriate? Then you would reasonably resist defining nuclear warheads as conventional weapons, and you would have a good reason to vote for Lyndon J ohnson. But if not, not or worse. Mandy Grunwald explained on C-SPAN that many anti-Clinton spots made by Alex Castellanos for Bob Dole in 1996 offered scorn, outrage, and hatred sharable only by a small part of the electorate. The focus groups and surveys she saw showed that few people accepted the argumentative terms of those spots, because their feelings were not the same. The spots did reinforce right-wingers in their political terms as in their loathing of Clinton. Going over the top, however, the spots also reinforced most other viewers in their distrust of Dole as a sharp-tongued, immoderate candidate. Or so Grunwald interpreted the evidence available to her.

32 That emotions work as reasons explains the most enduring finding about political ads: that they reinforce previous dispositions of viewers toward candidates. Emotions performed or provoked by telespots that feel appropriate provide reasons to approve the candidate. Telespot emotions that feel inappropriate provide reasons to disapprove. Yet how telespot emotions feel depend in significant ways on viewers' prior feelings and judgments about the candidate. In a decently reasonable fashion, viewers become likely to resonate emotionally with spots for the candidates, with whom they already have shared experiences and judgments, while viewers are likely to feel irritated by emotions promoted by spots for opponents.

33 Many other dynamics inform reasoned responses to political advertising. Nonetheless this specifically emotional component in political reasoning is understandably (and defensibly) strong enough to surface weakly overall in media-effects research, when 
the others do not. Surely the most dispassionately analytical of scholars experience some resistance to emotions recommended by opposition spots, no matter how cogent and clever. Not unreasonably, these scholars also resist kinds of politics that are not their own (Nelson 1977). Yet such contrasting kinds of politics are different rationalities for politics, and these in turn can be distinct complexes of emotions.

\section{Political Rationalities}

If too much reason was a form of madness, then perhaps passionate reason was what was called for. Kim Stanley Robinson (2004, p. 250)

34 Postmodern people have particularly strong reasons to regard rationality and reason as implicitly plural nouns. Thus rhetorical theorists of the good-reasons school take all persuasion to appeal to many reasons (Booth 1970, 1988; Perelman 1969, 1982; Toulmin 1964, 1970). That there are many reasons means that there are many rationales: there are many reasonable ways to think through experiences and challenges to action. Yet this means that there are multiple rationalities. For many purposes, as already suggested, the modern, instrumental, technical rationality of calculating efficient means to given ends should be conceived as a distinctive complex of emotions and images. It is cool (dispassionate, impersonal) reason - in the many senses of that word. But the reverse holds as well: each complex of emotion, imagination, and cognition can be practiced as a specific mode of reasoning.

35 Historically there have been several of these styles unto rationalities within western politics: bureaucratic, courtly, realist, and republican (Hariman 1995). In modern times, each political ideology provides a logic of ideas that amounts to a distinctive rationality for politics (Nelson 1977, 1980). In European terms, these include authoritarianism, liberalism, socialism, conservatism, fascism, anarchism, and more. In moving into postmodern times, we augment those modern ideologies with further forms (and just not contents) of political ratiocination: environmentalism, existentialism, feminism, perfectionism, etc. (Nelson 1998, pp. 205-230). These function as different rationalities for politics. They cultivate different complexes of experience, emotion, imagination, and cognition. Hence they make different connections. 
36 Even if we were to focus on the hardboiled, instrumental rationality that modern idea-logics can be argued to share, we would learn that postmodern politics depart from idea-logics in favor of other, richer, softer, warmer, more substantive, differently directed and constrained reasoning. Modern rationalities for politics are primarily conductive, deductive, inductive, and reductive; whereas postmodern rationalities are far more abductive (Hanson 1965; Rawls 1971, 1996), coductive (Booth 1988), retroductive (Hanson 1969a, 1969b), and seductive (Baudrillard 1990). Modern rationalities pursue Newtonian, billiard-ball causation; postmodern rationalities stress non-linear systems with sensitive dependence and butterfly effects (Gleick 1987, 1990). Modern rationalities correlate independent and dependent variables; postmodern rationalities measure chaotic flows and tipping points (Hayles 1991; Gladwell 2002). Modern rationalities seek leverage for the control and domination of nature; even as their politics use governments, interest groups, and parties to leverage societies from outside. Postmodern rationalities diffuse, infuse, and overflow ecosystems; just as their movements turn politics into ethics, rhetorics, and aesthetics for direct action inside societies (Nelson 2004c). And all the while, pre-modern kinds of political rationality such as republicanism linger or return as alternatives too (Roelofs 1976).

37 Sometimes we can miss this in the American fascination with placing politics on a single spectrum of ideological positions from Left to Right. This is possible mainly because Americans have subscribed mostly to variants of one modern ideology for politics. In European terms, this is liberalism or liberal democracy (Reid 1972, 1974; Holsworth 1987). In the parlance of political theorists, this is liberalism with a small- 1 . It regards government as a necessary evil, it stresses individual rights, and it celebrates private life. In addition to American, large- L, "Liberalism" on the "Left," this even includes the Moderate middle of the road and most of what Americans call "Conservatism" on the "Right." For these differ mainly on which decisions to make public or leave private. The United States has been so homogeneous in its singular political ideology that scholars can slip into thinking that there is only one political rationality, defined in purely formal terms of logos that exclude all pathos and can process any sort of political content.

38 That one-ideology era might be ending for America's official politics, the high politics of state (Wills 1969). Even if not, comparisons to other countries and cultures disclose additional 
ideologies for politics. Increasing attention to cultural and movement politics within the United States also raises awareness of other rationalities that operate more obviously outside the state (Cohen 1985; Luke 1989; Nimmo 1990; Fieschi 2004). Yet political spots on television show that politics beyond those of liberal democracy make prominent appearances in American elections. To see this, we need to sidestep the mainstream paradigm for studying ads. Rather than target their consequences for voting, in terms of turnout or victors, we do well to examine campaign spots for the various politics that they make available (Nelson 2004a, 2004b).

39 The United States was founded as a republic, and the politics of republics linger in daily conduct as well as governing institutions. Yet the country rapidly became so liberal in ideology that competing logics of ideas never gained much traction, and liberal individualism in the U.S. soon appropriated sentiments along with some devices of democracy that celebrate deference to ordinary people in collective modes of voice (Nelson 2001). So it is understandable that liberal politics of representation have dominated the discipline of political science, its conceptions of American politics, and its studies of campaign spots. The academic mania for media effects is one result (Nelson 2004a). Liberalism downplays the importance of immaterial symbols and other communications, aside from their impact on the behavior of human individuals, especially their votes in elections and their opinions for surveys.

40 Notwithstanding empirical and analytical explanations that plurality contests in single-member districts cannot confer representational mandates, almost all election research focuses on candidate representation of voter interests (Dahl 2001). Thus studies of election ads feature the liberal politics of taking or criticizing "positions on issues" (J amieson 1984; West 2001). The complaints against attack ads worry not only that they depress turnout but that they obscure or distort issue positions (J ohnsonCartee 1991; J amieson 2000). Hence researchers have worked mainly to specify ad effects on citizen preferences for policies or candidates.

41 The trouble is not that the liberal paradigm makes no sense for American elections; it is that even American campaigns turn importantly on politics beyond liberalism. Every position on the American spectrum of Left-Center-Right is a version of European liberalism inflected by American senses of democracy. Yet 
historians and theorists notice a fundamentally wider field of ideologies in America, encompassing conservatism and socialism as well as liberalism (Ball 1999; Heywood 2003). Rhetoricians see in America's popular culture a range of political styles that include realism, bureaucratism, and republicanism (Hariman 1995). Political sociologists recognize in America's civil society diverse movement politics of feminism, environmentalism, populism, and more (Cohen 1985; Dryzek 2002; Fieschi 2004; Tarrow 1994).

42 Various political movements, styles, and ideologies not only can but often do surface in campaign ads. There they promote distinctive emotions and appeal to rationalities constructed by politics different from liberalism. Thus presidential ads for the 2000 general election proved remarkably populist - as well as liberal - in their visual and verbal devices, while their voices were strongly republican in style. Then ads for the 2004 caucuses extended the prominence of populism into voicing as well (Nelson 2004b).

43 Current republicanism in the United States has no special connection to the GOP, which has become far more committed to tenets of ideology featured by liberalism and conservatism in European terms. Therefore republicanism persists less in America's official politics than in its residual structures of government, its everyday talk of character and community, as well as its popular genres (Bellah 1985; Nelson 2003). As a style, republicanism regards government as good, emphasizes citizen responsibilities, and seeks personal fulfillment in public affairs. This makes for stark contrasts with liberalism, which takes the state to be a necessary evil, celebrates citizen rights, and promotes personal development in private activities. Liberalism wants wellinformed citizens who express their interests effectively through groups. Republicanism wants inspirited citizens who recognize their interests when articled by leaders. Knowing with Lord Acton that power tends to corrupt, liberals want representative leaders regularly elected to keep them accountable to private citizens. Knowing with Machiavelli that power tends to disperse, republicans want virtuoso leaders able to survive the slings and arrows of outrageous fortune.

44 Populism wants charismatic leaders who stand for the little man more than any platform of policies. It often glorifies government as a crusade for the common people while demonizing specific officials as lackeys of the special interests. It promises radical reform to sweep clean the corridors of power even as it caters to 
the consumer satisfaction of ordinary citizens. It favors politicians who display a common touch with down-home taste. These leaders are aggressive voices of and for the people. There are populisms of Right and Left, but these are not the liberal politics of issue positions and problem solutions. In other words, they are not the politics that most political scientists promote in the interest of representative government. Nor are they the republican politics of portentous oratory that dominated early stump speeches then carried over into political telespots with rotund voiceovers to declaim candidate virtues or opponent vices.

45 In the United States, populism has been more a movement than an ideology. Ad politics that depart from liberalism are seldom ideological in a strict sense (Nelson 1998, pp. 205-230). Unlike ideologies, political styles (like republicanism) and movements (like populism) do not develop themselves into sciences of societies. Thus modern ideologies offer logics-of-ideas for explaining societies and changing policies. They act indirectly on civil society by using modern government as a lever. Political styles and movements instead emphasize direct action by some citizens on others within civil society. They try to alter our everyday conduct by changing our ethics, rhetorics, and aesthetics. Yet styles and movements need be no less political rationalities for favoring ethics, rhetorics, and aesthetics over idea logics. Even the divergent rationalities of sciences such as chemistry, psychology, economics, and ecology can be seen as distinctive webs of values, inventions, and emotions (Lakatos 1970; Feyerabend 1975; Kuhn 1977; Nelson 1987).

46 In emotional terms, liberal rationality is the epitome of modern reason: cool, calm, and collected; serious, sincere, and concerned. In voice, consequently, it can sound earnest, wooden, unexcited and unexciting. Populist rationality is emphatically sentimental: angry or irritated, sad or scornful, disbelieving or enthusiastic. In voice, populist reason is pointedly ordinary and unpretentious; in tone, this means greater variation than can readily be heard from (scientific) liberals and (oratorical) republicans. Populist voices are adamant or dramatic, edgy or urgent, indignant or virulent, harsh or scolding, friendly or warm. Considered for its main complex of emotions, republican rationality is more formal and decorous than the other two. Typically it is admiring, caring, or cheerful; ominous, proud, or solemn. Accordingly republican voices often are authoritative or energetic, reassuring or portentous, pretentious or even stern. Appeals to all three of these political rationalities are evident in 2004 presidential spots 
(Nelson 2004a, 2004b).

47 Thus political ads show how human emotions help form distinct rationalities for politics. This is a reason to open the analysis of campaign spots to politics beyond liberal representation of interests. Then we have better opportunities to appreciate the emotional appeals in political advertising as potentially legitimate and practically essential to its rhetorical work.

48 Theories of public argument typically stress claims, warrants, and backings as the units of analysis for public persuasion. Yet the video rhetorics in political spots often work through speech acts other than claiming, and these bring emotions emphatically into the picture. Spots make these speech acts with words, but also with sights and sounds that position television and film closer to oratory and drama than textual modes of public address. Political spots depend on gestures, icons, musics, genres, tones of voice, as well as special effects in sound, lighting, and editing that cannot be appreciated adequately by turning campaign spots into scripts. And even when political spots advance claims, they evidence less by means of anecdotes, authorities, statistics, or other devices of verbiage than through vicarious and virtual experiences that address the full-bodied feelings of citizens. It is high time for us to appreciate the diverse appeals and politics in public arguments of all kinds.

(C) J ohn S. Nelson, 2005.

\section{References}

Alter, J onathan. 1990. “The Media Mud Squad.” Newsweek, 116, 18, October 29, p. 37.

Ansolabehere, Stephen, and Shanto Iyengar. 1995. Going Negative: How Political Advertisements Shrink and Polarize the Electorate. New York: Free Press.

Ansolabehere, Stephen, and Shanto Iyengar. 1996. "Can the Press Monitor Campaign Advertising?" Press/ Politics, 1, 1, February, pp. 72-86.

Aristotle. 1991. Aristotle on Rhetoric: A Theory of Civic Discourse, George A. Kennedy, ed. and tr. Oxford: Oxford University Press. 
Auerbach, Erich. 1953. Mimesis. Princeton, NJ : Princeton University Press.

Ball, Terence Ball, and Richard Dagger. 1999. Political Ideologies and the Democratic Ideal. New York: Longman, (1991, 1995), third edition.

Baudrillard, J ean. 1990. Seduction. Brian Singer, tr. New York: St. Martin's Press (1979).

Bellah, Robert N., Richard Madsen, William M. Sullivan, Ann Swidler, and Steven M. Tipton. 1985. Habits of the Heart: Individualism and Commitment in American Life. Berkeley: University of California Press.

Biocca, Frank, ed. 1991. Television and Political Advertising, Volume 1: Psychological Processes. Hillsdale, NJ : Lawrence Erlbaum Associates.

Billig, Michael. 1989. Arguing and Thinking. Cambridge: Cambridge University Press.

Booth, Wayne C. 1970. Now Don't Try To Reason with Me. Chicago: University of Chicago Press.

Booth, Wayne C. 1988. The Company We Keep. Berkeley: University of California Press.

Boynton, G. R. 1995. "Computational Modeling: A Computational Model of a Survey Respondent." In Milton Lodge and Kathleen M. McGraw, eds., Political J udgment. Ann Arbor: University of Michigan Press, pp. 229-248.

Boynton, G. R. 1996. The Art of Campaign Advertising. Chatham, NJ : Chatham House, CD-ROM.

Boynton, G. R., and J ohn S. Nelson. 1997. Hot Spots: Multimedia Analyses of Political Ads. Urbana: University of Illinois Press, videotape.

Brader, Ted. 2005. "Striking a Responsive Chord: How Political Ads Motivate and Persuade Voters by Appealing to Emotions." American J ournal of Political Science, 49, 2, April, pp. 388-405. 
Broder, David S. 1990. "A Five-Point Plan to Return Campaigns to Voters." Des Moines Register, [Washington Post Service], J anuary 21, C1 and C3.

Brodkey, Harold. 1985. "Reading, the Most Dangerous Game." New York Times Book Review, 90, 47, November 24, pp. 1 and 44-45.

Cohen, J ean L., ed. 1985. Special issue on "Social Movements." Social Research, 52, 4, Winter, pp. 663-890.

Combs, J ames E., and Dan Nimmo. 1993. The New Propaganda: The Dictatorship of Palaver in Contemporary Politics. New York: Longman.

Dahl, Robert A. 2001. How Democratic Is the American Constitution? New Haven, Yale University Press.

Damasio, Antonio R. 1994. Descartes' Error: Emotion, Reason, and the Human Brain. New York: Putnam.

Damasio, Antonio R. 1999. The Feeling of What Happens: Body and Emotion in the Making of Consciousness. New York: Harcourt Brace.

Damasio, Antonio R. 2003. Looking for Spinoza: J oy, Sorrow, and the Feeling Brain. Orlando: Harcourt.

DeLuca, Kevin Michael. 1999. Image Politics. New York: Guilford Press.

Dryzek, J ohn S., David Downes, Christian Hunold, David Schlosberg, and Hans-Kristian Hernes. 2002. Green States and Social Movements: Environmentalism in the United States, United Kingdom, Germany, and Norway. London: Routledge.

Eco, Umberto. 1983. The Name of the Rose, William Weaver, tr. New York: Harcourt Brace J ovanovich, (1980).

Fieschi, Catherine, ed. 2004. Special issue on "Populism." J ournal of Political Ideologies, 9, 3, October, pp. 235-327.

Fiske, Susan T., and Shelley E. Taylor. 1991. Social Cognition. New York: McGraw-Hill, (1984), second edition. 
Frank, Robert H. 1988. Passions within Reason. New York: Norton.

Galston, William A. 1989. "The Obligation to Play Political Hardball." Philosophy and Public Policy, 9, 1, Winter, pp. 6-9.

Gladwell, Malcolm. 2002. The Tipping Point: How Little Things Can Make a Big Difference. Boston: Little, Brown, (2000), expanded edition.

Gleick, J ames. 1987. Chaos: Making a New Science. New York: Viking Press.

Gleick, J ames. 1990. Nature’s Chaos. New York: Viking Press.

Graber, Doris A. 1988. Processing the News. New York: Longman, second edition.

Graber, Doris A. 2001. Processing Politics. Chicago: University of Chicago Press.

Hanson, Norwood Russell. 1965. Patterns of Discovery. New York: Cambridge University Press.

Hanson, Norwood Russell. 1969a. "Retroduction: Scientists Are Not Confined to the H-D Method." In Leonard I. Krimerman, ed., The Nature and Scope of Social Science. New York: Appleton-Century-Crofts, pp. 69-72.

Hanson, Norwood Russell. 1969b. "Retroduction and the Logic of Scientific Discovery." In Leonard I. Krimerman, ed., The Nature and Scope of Social Science. New York: AppletonCentury-Crofts, pp. 73-83.

Hariman, Robert. 1995. Political Style: The Artistry of Power. Chicago: University of Chicago Press.

Hart, Roderick P. 1994. Seducing America: How Television Charms the Modern Voter. New York: Oxford University Press.

Hayles, N. Katherine, ed. 1991. Chaos and Order: Complex Dynamics in Literature and Science. Chicago: University of Chicago Press. 
Heywood, Andrew. 2003. Political Ideologies: An Introduction. London: Palgrave Macmillan, third edition, (1992, 1998).

Holsworth, Robert D., and J. Harry Wray. 1987. American Politics and Everyday Life. New York: Wiley, (1982), second edition.

Huddy, Leonie, and Anna H. Gunnthorsdottir. 2000. "The Persuasive Effects of Emotive Visual Imagery." Political Psychology, 21, 4, November, pp. 745-778.

Hume, David. 1739-40. A Treatise of Human Nature. Oxford: Oxford University Press (2000).

Hume, David. 1777. An Enquiry Concerning Human Understanding. Oxford: Oxford University Press (1999).

J amieson, Kathleen Hall. 1984. Packaging the Presidency. New York: Oxford University Press.

Jamieson, Kathleen Hall. 1992. Dirty Politics: Deception, Distraction, and Democracy. New York: Oxford University Press.

J amieson, Kathleen Hall. 2000. Everything You Think You Know about Politics ... and Why You're Wrong. New York: Basic Books.

J ay, Martin. 1993. Downcast Eyes. Berkeley: University of California Press.

J ohnson-Cartee, Karen S., and Gary A. Copeland. 1991. Negative Political Advertising. Hillsdale, NJ : Erlbaum.

J owett, Garth S., and Victoria O’Donell. 1986. Propaganda and Persuasion. Newbury Park, CA: Sage.

Kuhn, Thomas S. 1977. The Essential Tension: Selected Studies in Scientific Tradition and Change. Chicago: University of Chicago Press.

Kurtz, Howard. 1996. "GOP Candidates Cry Foul as Their Attack Ads Bend the Rules to Elbow Rivals." Washington Post, J anuary 18. 
Lakatos, Imre, and Alan Musgrave, eds. 1970. Criticism and the Growth of Knowledge. New York: Cambridge University Press.

le Carré, J ohn. 1996. The Tailor of Panama. New York: Knopf.

Lodge, Milton, and Kathleen McGraw, eds. 1995. Political Judgment. Ann Arbor: University of Michigan Press.

Luke, Timothy W. 1989. Screens of Power: Ideology, Domination, and Resistance in Informational Society. Urbana: University of Illinois Press.

Nelson, J ohn S. 1977. "The Ideological Connection, Parts I-II." Theory and Society, 4, 3-4, Fall-Winter, pp. 421-448 and 573-590.

Nelson, J ohn S. 1980. “Ashcraft's Problem of Ideology.” J ournal of Politics, 42, 3, August, pp. 709-715.

Nelson, J ohn S. 1983. "Political Theory as Political Rhetoric.” In Nelson, ed., What Should Political Theory Be Now? Albany: State University of New York Press, pp. 169-240.

Nelson, John S., Allan Megill, and D. N. McCloskey, eds. 1987. The Rhetoric of the Human Sciences: Language and Argument in Scholarship and Public Affairs. Madison: University of Wisconsin Press.

Nelson, J ohn S., and G. R. Boynton. 1997. Video Rhetorics: Televised Advertising in American Politicss. Urbana: University of Illinois Press.

Nelson, J ohn S. 1998. Tropes of Politics. Madison: University of Wisconsin Press.

Nelson, J ohn S. 2000. "Argument by Mood in War Movies." In Thomas A. Hollihan, ed., Argument at Century's End. Annandale, VA: National Communication Association, pp. 262-269.

Nelson, J ohn S. 2001. “The Republic of Myth.” Foundations of Political Theory Annual Workshop on Political Myth, Rhetoric, and Symbolism, San Francisco, CA. 
Nelson, J ohn S. 2003. "Four Forms for Terrorism: Horror, Dystopia, Thriller, and Noir." Poroi, 2, 1, August, http://inpress.lib.uiowa.edu/ poroi/ papers/ nelson030815.h tml.

Nelson, J ohn S., and Anna Lorien Nelson, 2004a. "Politics of Sight and Sound: Appeals in Iowa Caucus Ads for 2004." Annual Meeting of the Midwest Political Science Association, Chicago, IL.

Nelson, J ohn S. 2004b. "The Summer of Our Disbelief: Wars, Courts, Trade, Identities, Experiences ... and Campaigns," Poroi, 3, 1, J une, http:/ inpress.lib.uiowa. edu/poroi/papers/ nelson040624.html.

Nelson, J ohn S. 2004c. "Representation and Its Discontents: Figures for Post-Western Politics." Second Conference of the Association for Political Theory, Colorado Springs, CO.

Nelson, J ohn S. 2004d. "The Passion of the Film: Cinematic Modes of Empathy in the Service of Moral Action," Poroi, 3, 2, December, 2004, http://inpress.lib.uiowa.edu/ poroi/papers/ nelson041001.html.

Nesbitt, Richard E., and Ross, Lee. 1980. Human Inference. Englewood Cliffs, NJ : Prentice-Hall.

Nimmo, Dan, and J ames E. Combs. 1990. Mediated Political Realities. New York: Longman, (1983), second edition.

Patterson, Thomas E. 1980. The Mass Media Election. New York: Praeger.

Patterson, Thomas E. 1993. Out of Order. New York: Knopf.

Perelman, Chaim, and Olbrechts-Tyteca, Lucie. 1969. The New Rhetoric. J ohn Wilkinson and Purcell Weaver, trs. Notre Dame, IN: University of Notre Dame Press.

Perelman, Chaim. 1982. The Realm of Rhetoric, William Kluback, tr. Notre Dame, IN: University of Notre Dame Press.

Pirsig, Robert M. 1974. Zen and the Art of Motorcycle Maintenance. New York: Bantam. 
Rawls, J ohn. 1971. A Theory of J ustice. Cambridge, MA: Harvard University Press.

Rawls, J ohn. 1996. Political Liberalism. New York: Columbia University Press, (1993), second edition.

Reid, Herbert G. 1972. "Contemporary American Political science in the Crisis of Industrial Society." American J ournal of Political Science, 16, 3, August, pp. 339-366.

Reid, Herbert G., ed. 1974. Up the Mainstream: A Critique of Ideology in American Politics and Everyday Life. New York: McKay.

Richardson, Glenn W., J r. 2003. Pulp Politics: How Political Advertising Tells the Stories of American Politics. Lanham, MD: Rowman and Littlefield.

Robinson, Kim Stanley. 2004. Forty Signs of Rain. New York: Bantam Books.

Roelofs, H. Mark. 1976. Ideology and Myth in American Politics. Boston: Little, Brown.

Scarry, Elaine. 1994. Resisting Representation. New York: Oxford University Press.

Stephenson, Neal. 1988. Zodiac. New York: Bantam Books.

Szasz, Andrew. 1994. EcoPopulism. Minneapolis: University of Minnesota Press.

Tarrow, Sidney. 2004. Power in Movement: Social Movements, Collective Action and Politics. New York: Cambridge University Press.

Taylor, Paul, 1990a. "Armed with Distortions, Candidates Attack." Washington Post, September 21, pp. A1 and A10.

Taylor, Paul. 1990b. See How They Run: Electing the President in an Age of Mediaocracy. New York: Knopf.

Toulmin, Stephen. 1964. The Uses of Argument. Cambridge: Cambridge University Press. 
Toulmin, Stephen. 1970. Reason in Ethics. Cambridge: Cambridge University Press.

West, Darrell M. 1992. "Reforming Campaign Ads.” PS, 25, 1, March, pp. 74-77.

West, Darrell M. 2001. Air Wars: Television Advertising in Election Campaigns, 1952-1996. Washington, DC: Congressional Quarterly, (1993, 1997), third edition.

Wills, Garry. 1969. Nixon Agonistes: The Crisis of the Self-Made Man. Boston: Houghton Mifflin. 